\title{
Importance of local production versus pelagic subsidies in the diet of an isolated population of bottlenose dolphins Tursiops sp.
}

\author{
Susan Mærsk Lusseau ${ }^{1,2}$, Stephen R. Wing ${ }^{1, *}$ \\ ${ }^{1}$ Department of Marine Science, PO Box 56, University of Otago, Dunedin, New Zealand \\ ${ }^{2}$ Lighthouse Field Station, University of Aberdeen, School of Biological Sciences, George Street, Cromarty IV11 8 YJ, UK
}

\begin{abstract}
Isolated populations can be strongly influenced by patterns in the local production of food, and by subsidies from outside sources. We used stable-isotope analysis to investigate the relative importance of autochthonous food resources versus pelagic subsidies in the diet of the isolated population of bottlenose dolphins Tursiops sp. inhabiting Doubtful Sound, New Zealand. Samples of the primary carbon sources (macroalgae, phytoplankton and chemoautotrophs) as well as potential food sources (fish and squid) were collected from Doubtful Sound and analysed for $\delta^{13} \mathrm{C}$ and $\delta^{15} \mathrm{~N}$. Isotopic signatures of fishes fell along a gradient from very depleted values for deep benthic species, particularly hagfish Eptatretus cirrhatus $\left(\delta^{13} \mathrm{C}-23.6, \delta^{15} \mathrm{~N} 6.3\right)$, to intermediate values for pelagic species $\left(\delta^{13} \mathrm{C}-18.1, \delta^{15} \mathrm{~N} 11.3\right)$ and more enriched values for reef-associated species $\left(\delta^{13} \mathrm{C}-16.1, \delta^{15} \mathrm{~N}\right.$ 14.4). Exfoliated skin tissue was collected from live dolphins $(\mathrm{n}=11)$ and used to estimate the isotopic signature of dolphin diet $\left(\delta^{13} \mathrm{C}-15.4, \delta^{15} \mathrm{~N} 14.2\right)$. The position of this estimate at the most enriched end of the range of isotopic signatures indicated that there was likely minimal mixing of resources from different habitats and that a majority of the dolphin population's diet came from rocky reef and demersal habitats. Estimates of $\delta^{13} \mathrm{C}$ and $\delta^{15} \mathrm{~N}$ for dolphin diet were compared with isotopic signatures of the different primary carbon sources using a multiple-source mixing model. Both results suggest that the diet of this population was primarily made up of autochthonous carbon production with a large contribution from benthic macroalgae, rather than pelagic subsidies from outside of the Sound.
\end{abstract}

KEY WORDS: Bottlenose dolphin $\cdot$ Diet $\cdot$ Fjord $\cdot$ Stable isotopes $\cdot$ Isolated population

\section{INTRODUCTION}

The bottlenose dolphins Tursiops sp. that inhabit Doubtful Sound are effectively isolated from conspecifics within other parts of the Fiordland region in southwest New Zealand (Haase \& Schneider 2001, Lusseau et al. 2003). These animals comprise a closed or semi-closed population, based on $12 \mathrm{yr}$ of continuous study over which investigators did not observe immigrations or emmigrations, and only rare excursions outside the fjord were recorded (Schneider 1999, Lusseau et al. 2003). The population of 67 dolphins in 2002 required in excess of $200 \mathrm{t}$ of fish per year for maintenance, based on calculations using nutritional requirements from captive animals (Kastelein et al. 2002). This resource requirement is likely supported by a mixture of primary production generated inside the fjord (phytoplankton, macroalgae, and terrestrial input) and an influx of oceanic production into the system in the form of migrating pelagic fishes. As a result, the following interesting question is posed: How important is local production versus pelagic subsidies for supporting the isolated population of bottlenose dolphins in Doubtful Sound?

Bottlenose dolphins are opportunistic predators with a diet reflecting a preference for, and the availability of, food resources (e.g. Cockroft \& Ross 1990, Corkeron et al. 1990). An extensive study on diving patterns of 
the population in Doubtful Sound was conducted by Schneider (1999), leading to inferences about the dolphin's habitat use and diet composition. His study suggested that foraging extended to each of the available habitats to varying extents. Although dives to $220 \mathrm{~m}$ depth were recorded, greater than $90 \%$ of dives were less than $100 \mathrm{~m}$ depth. Schneider (1999) observed dolphins more than $70 \%$ of the time foraging individually within $50 \mathrm{~m}$ of the shoreline. Synchronous diving, indicating co-operative feeding, was more commonly noted in open waters. These observations are consistent with the idea that the dolphin feeding effort was concentrated on rocky reefs with occasional visits to the deep basins and seasonal consumption of schooling pelagic fishes and squid.

Over the last $12 \mathrm{yr}$, numerous observations have been made of dead or injured fish in the wake of dolphin groups feeding in Doubtful Sound. The fishes collected came from the full range of habitats available within the fjord, including deep basins (rattails Caelorinchus spp., hagfish Eptatretus cirrhatus), rocky reefs (spotty Notolabrus celidotus, conger eel Conger verrauxi, hapuku Polyprion oxygeneios) and the pelagic zone (mackerel Scomber australasicus and Trachurus declivis). While the relative importance of any of these prey items is not known, these observations, in addition to observations of foraging behaviour (Schneider 1999), indicate a broad potential use of prey species.

There is evidence that resource limitation may have influenced the reproductive fitness of the study population. For example, the population has been stable in numbers over the last decade and has a pronounced seasonal breeding season (Haase \& Schneider 2001). The existence of a distinct breeding season in bottlenose dolphins has been linked to seasonal increases in availability of resources to pregnant and lactating females (Urian et al. 1996). This suggests that resources may have been limited for successful reproduction in the study population outside of this season. These population characteristics present a special case for studying marine mammal diet using stable-isotope analysis and an excellent opportunity to closely analyse food sources of an upper-trophic-level predator. Very few marine mammal populations are isolated to this extent, and fewer still inhabit semi-enclosed environments such as Doubtful Sound, where local production can potentially be distinguished from subsidised production.

The ratio of naturally occurring isotopes is an effective tracer of energy and nutrient flow in ecosystems (e.g. Fry \& Sherr 1984, Petersen \& Fry 1987, Wada et al. 1991). $\delta^{15} \mathrm{~N}$ and $\delta^{13} \mathrm{C}$ in animal tissues reflects that of the diet used for tissue synthesis, with predictable fractionation between trophic levels (DeNiro \& Epstein
1978, 1981, Petersen \& Fry 1987, McCutchan et al. 2003). The contribution of different categories of prey in the diet of a consumer could therefore be assessed provided the prey had distinct isotopic signatures (Rau et al. 1992, Hobson et al. 1996). It is thus possible to derive information about the diet of the animal by analysing the isotopic composition of the whole animal, or representative tissues, as well as potential food items (e.g. Das et al. 2003). Stable-isotope analysis of body tissues provides information on assimilation of diet integrated over time (Tieszen et al. 1983), in contrast to stomach content analysis, which provides only short-term information on ingestion.

In the present study, we used stable-isotope analysis to investigate whether isotopic signatures were distinct among primary carbon sources and among 23 common fish species that inhabit Doubtful Sound. We then analysed whether distinct habitats within Doubtful Sound harboured groups of fishes with distinct isotopic signatures. $\delta^{13} \mathrm{C}$ and $\delta^{15} \mathrm{~N}$ in the diet of bottlenose dolphins were estimated using isotopic signatures from exfoliated skin samples. With these data we investigated whether it is possible to distinguish the composition of fishes, and primary carbon sources, that likely contribute to the diet of dolphins in the fjord, with particular focus on the question of whether their diet is composed from local production or subsidies from outside of the fjord system.

\section{PHYSICAL SETTING - HABITATS IN STUDY AREA}

Doubtful Sound $\left(45^{\circ} 30^{\prime} \mathrm{S}, 167^{\circ} 00^{\prime} \mathrm{E}\right)$ is one of 14 fjords indenting the southwestern coast of the South Island, New Zealand (Fig. 1). The main reaches and arms of the fjord are bordered by steep, almost vertical rock walls extending to depths of up to $434 \mathrm{~m}$ at the edges of the deep sedimentary basins. Shallow sills $(120$ to $128 \mathrm{~m})$ are present at the 2 entrances of the fjord as well as between the deep basins. Freshwater input from over 150 separate streams and rivers as well as from the Manapouri hydroelectric power plant results in a persistent low-salinity layer in the surface waters of the fjord as well as a pronounced gradient in salinity along the length of the fjord (Gibbs et al. 2000). This, along with strong gradients in wave exposure and light, creates a spectrum of physical habitats in close proximity within Doubtful Sound, from waveexposed algal reefs around the entrances of the fjord to expanses of upper estuarine habitat at the head of each arm.

The pelagic zone of Doubtful Sound is a direct continuation of the Tasman Sea, and resource subsidies in the form of migrating pelagic fishes can enter the fjord unobstructed. This can be observed during warm-water 


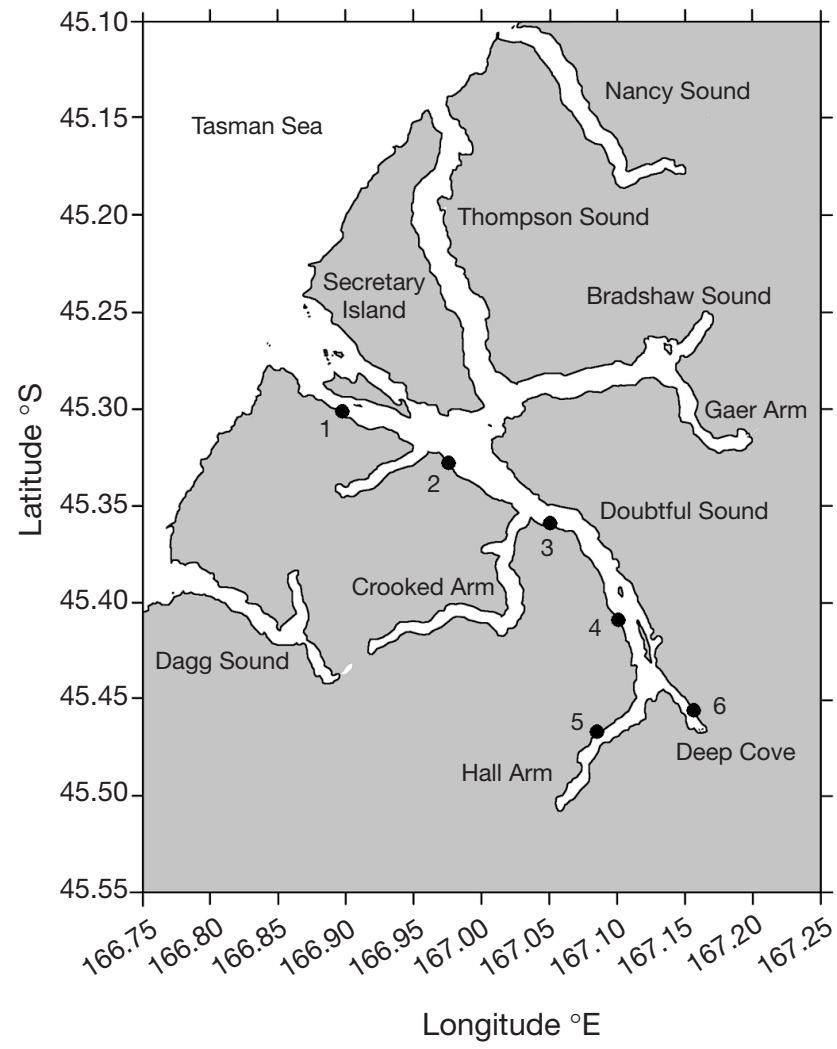

Fig. 1. Doubtful Sound, New Zealand, showing algal (1-6) and suspended particulate organic material collection sites (1, 3 and 6$)$

periods in the summer, when large schools of mackerel (Carangidae), squid and even tuna (Thunnidae) migrate into the fjord from the open coast, where they are fuelled by phytoplankton production (Goebel et al. 2005).

Along the sides of the fjord, rocky reefs and steep rock walls are a common habitat (Grange et al. 1981). This habitat is fragmented and isolated from similar habitats in neighbouring fjords. Many of the associated fish species are relatively sedentary or closely tied to the reef, and there is evidence that these fishes and other organisms from rocky habitats comprise more isolated populations than their outer coast equivalents (e.g. Perrin et al. 2004). The main primary producers in this habitat are macroalgae and benthic microalgae.

Due to the pronounced U-shape of the submerged glacial valleys, deep basins make up the largest area of habitat inside Doubtful Sound after the pelagic zone. Although organic material from benthic and pelagic producers in the surrounding communities ultimately ends up in the basins, the largest source of organic material to this habitat is likely to be terrestrial matter falling directly into the fjord and transported from the surrounding catchments (Pickrill 1987). Landslides occur regularly, causing large sections of forest from the mountainsides above to slide into the fjord. In the basins, this source of energy is likely made available to the food web via bacteria and chemoautotrophs.

At the head of each arm of the fjord, the environment is estuarine in character due to the large freshwater input, and only organisms with a high tolerance to freshwater are found in the shallow-water regions (Rutger \& Wing 2006). The soft-sediment communities here also receive a large input of terrestrial material from the river catchments.

\section{MATERIALS AND METHODS}

Carbon sources. Samples of suspended particulate organic material (SPOM, $\mathrm{n}=15$ ), were collected from a depth-stratified $(1,5$ and $10 \mathrm{~m})$ series of 51 water samples from 3 regions in the fjord (Fig. 1). Each sample was fractionated by size class $(>200,200-20$ and $<0.7 \mu \mathrm{m}$ ) on pre-combusted $25 \mathrm{~mm}$ glass fiber filters (Whatman $\mathrm{GF} / \mathrm{F})$ and frozen $\left(-80^{\circ} \mathrm{C}\right)$ until later analysis. The largest size class was excluded from the analysis. Microscopic examination of the samples revealed an abundance of chained and thecate diatoms, consistent with more intensive studies of the phytoplankton community (Goebel et al. 2005). Filters were dried at $60^{\circ} \mathrm{C}$ and packed in individual tin capsules prior to isotopic analyses.

Samples of Ulva sp. $(\mathrm{n}=21)$ and Ecklonia radiata $(\mathrm{n}=$ 14) were collected from a series of 6 sites along the axis of Doubtful Sound (Fig. 1). Ulva sp. was collected from the low-salinity layer, where it makes up a large fraction of the available biomass, and E. radiata was collected from depths of 10 to $15 \mathrm{~m}$, where the kelp is the most common large brown alga in the system. Samples of terrestrial detritus $(\mathrm{n}=4)$ and the chemoautotrophic clam Solemya parkinsoni (n = 5) were collected from Deep Cove at the head of Doubtful Sound. Each of the samples was dried at $60^{\circ} \mathrm{C}$ and homogenised to a fine powder using a mortar and pestle. A subsample of $1 \mathrm{mg}$ of each sample was prepared for $\delta^{13} \mathrm{C}$ and $\delta^{15} \mathrm{~N}$ analysis.

Stable-isotope characteristics of prey base. Samples from 23 fish species were collected inside Doubtful Sound between January and November 2002, including the most abundant fishes encountered among the primary habitats in the fjord (Francis \& Ling 1985). Francis (1988) was used as a guide for species identification. The majority of fishes were caught using hand lines or drop lines with lures, and some were caught using small-meshed set-nets. Fishing effort was concentrated in the area from Deep Cove to Crooked Arm including Hall and Crooked Arms as well as sites in Bradshaw Sound and Gaer Arm (Fig. 1). A section of muscle tissue was collected from each fish from between the lateral line and dorsal fin. This tissue was 
chosen for stable-isotope analysis because it varies the least in $\delta^{13} \mathrm{C}$ and $\delta^{15} \mathrm{~N}$ (Pinnegar \& Polunin 1999). The tissue was dried at $60^{\circ} \mathrm{C}$ before homogenisation to a fine powder using a mortar and pestle. Subsamples $\left(1 \mathrm{mg}\right.$ ) were prepared for $\delta^{13} \mathrm{C}$ and $\delta^{15} \mathrm{~N}$ analysis.

Bottlenose dolphin tissue samples. Skin samples of bottlenose dolphins from Doubtful Sound were collected under permit from the Department of Conservation, Southland Conservancy (dated 27 March 2002). Included in this contract was a program to assess the effects of sampling on dolphin behaviour. A Velcro ${ }^{\mathrm{TM}}$-pad was drawn across the dorsal surface of individual bow-riding dolphins and exfoliated skin cells trapped in the Velcro ${ }^{\mathrm{TM}}$ loops retrieved (similar to the method used in Harlin et al. 1999). The skin samples were removed with forceps from the Velcro ${ }^{\mathrm{TM}}$-pad under a dissecting microscope, and frozen $\left(-20^{\circ} \mathrm{C}\right)$ before processing. On return to the laboratory, samples were dried at $60^{\circ} \mathrm{C}$ until a constant weight was maintained. Due to the small sample sizes involved, only large samples ( $>0.5 \mathrm{mg}$ ) were homogenised using a mortar and pestle. The whole dried exfoliated skin samples were weighed, transferred to individual tin cups, and analysed for $\delta^{13} \mathrm{C}$ and $\delta^{15} \mathrm{~N}$ signatures.

Stable-isotope analysis. Analyses of $\delta^{13} \mathrm{C}$ and $\delta^{15} \mathrm{~N}$ were performed on a Europa 20-20 update stableisotope mass spectrometer interfaced to a Carlo Erba elemental analyser (NA1500) in continuous flow mode (Microanalytical Laboratory, Department of Chemistry, University of Otago, New Zealand; precision: $0.2 \%$ ). An EDTA laboratory standard reference was measured every 6 samples. This laboratory standard reference was supplied by Elemental Microanalysis (Cheshire, UK) and standardised against international standards (IAEACH-6 for carbon, IAEAN1 and IAEAN2 for nitrogen). The dolphin skin samples were analysed separately due to the small quantities available, with the mass spectrometer sensitivity adjusted accordingly. For these samples, a similarly sized standard reference was run every 3 samples. Results are expressed in the standard delta notation (e.g. Peterson \& Fry 1987).

Groupings of fishes. Mean values for $\delta^{13} \mathrm{C}$ and $\delta^{15} \mathrm{~N}$ of muscle tissue from each fish species were analysed using cluster analysis (Ward's minimum variance method). Since the cluster analysis of species means does not take into account variation within each species, discriminant analysis was performed on $\delta^{13} \mathrm{C}$ and $\delta^{15} \mathrm{~N}$ of individual fish assigned to groups following the cluster analysis of species. We also used analysis of variance (ANOVA) to test for differences in the $\delta^{15} \mathrm{~N}$ and $\delta^{13} \mathrm{C}$ signatures of the 3 cluster groups and the estimates of dietary signatures of the bottlenose dolphins, with species nested within cluster.

Fish samples were analysed for temporal variability by multivariate ANOVA (MANOVA) on a subset of the data. Only samples collected in the southern part of the fjord complex were used for the subset, since this group had the best representation among different seasons. Samples were divided into those collected in the austral summer and autumn versus those collected in winter and spring.

Habitat association among fishes. The fish species were divided into groups by habitat association based primarily on descriptions in Francis (1988), and for species not covered there, information was taken from www.fishbase.org. The proportional representation of fish species from different habitat categories in each cluster group was then calculated. Habitat categories were defined as pelagic, benthopelagic, demersal, deep basin, reef-associated and estuarine. The pattern of $\delta^{13} \mathrm{C}$ and $\delta^{15} \mathrm{~N}$ amongst fishes belonging to the different habitat categories was analysed. We used ANOVA to test for differences in the $\delta^{13} \mathrm{C}$ and $\delta^{15} \mathrm{~N}$ signatures of fishes in each habitat grouping and the estimates of dietary signatures of the bottlenose dolphins, with species nested within habitat grouping.

Tissue samples from bottlenose dolphins. $\delta^{13} \mathrm{C}$ and $\delta^{15} \mathrm{~N}$ of exfoliated skin from stranded bottlenose dolphins $(n=7)$ were demonstrated to differ from those of muscle tissue in a predictable way according to:

$$
\begin{gathered}
\delta^{13} \mathrm{C}_{\text {muscle }}=0.69 \times \delta^{13} \mathrm{C}_{\text {ex.skin }}-2.79 \\
\left(F_{1,5}=42.26, \mathrm{p}=0.001, \mathrm{r}^{2}=0.89\right) \\
\delta^{15} \mathrm{~N}_{\text {muscle }}=0.85 \times \delta^{15} \mathrm{~N}_{\text {ex.skin }}+4.31 \\
\left(F_{1,5}=19.12, \mathrm{p}=0.007, \mathrm{r}^{2}=0.79\right)
\end{gathered}
$$

We used these relationships to predict $\delta^{13} \mathrm{C}$ and $\delta^{15} \mathrm{~N}$ of muscle tissue of live animals in Doubtful Sound. A trophic correction factor of $2.95 \%$ for $\delta^{15} \mathrm{~N}$ and $1.2 \%$ for $\delta^{13} \mathrm{C}$ was subtracted from the predicted values for muscle tissue for individual dolphins to estimate isotopic values of assimilated prey items. These trophic-level correction factors were chosen to be intermediate between the ones observed between muscle tissue and the diet of seals (Hobson et al. 1996) and red foxes (Roth \& Hobson 2000). These are, to our knowledge, the most appropriate values for isotope fractionation from controlled feeding experiments involving mammalian carnivores (e.g. McCutchan et al. 2003).

Mixing model. We used the multiple-source mixing model 'isoerror' to estimate the contribution of the 3 primary carbon sources-macroalgae, SPOM and chemoautotrophs - to bottlenose dolphin diet (Phillips \& Gregg 2001). We used average values for incremental trophic enrichment of $\delta^{15} \mathrm{~N}(+2.4)$ and $\delta^{13} \mathrm{C}(+0.4)$ from McCutchan et al. (2003) to estimate the relative contribution of these sources to bottlenose dolphin diet, and we tested the sensitivity of the model to these assumptions. 


\section{RESULTS}

\section{Carbon sources}

Primary production inside Doubtful Sound is made up of isotopically distinct carbon source pools with discrimination by $\delta^{15} \mathrm{~N}$ and $\delta^{13} \mathrm{C}$ among samples of SPOM, attached benthic macroalgae, and chemoautotrophic production (Fig. 2). While this is not a comprehensive survey of the primary producers in the system, the range of isotopic signatures for these 3 basic sources corresponds closely with values from the literature in similar systems (e.g. France 1995, MacAvoy et al. 2002) and likely includes the most abundant carbon sources in Doubtful Sound.

\section{Stable-isotope characteristics of prey base}

During the course of this study, 255 fish belonging to 23 species, and 1 squid species, were analysed for $\delta^{15} \mathrm{~N}$ and $\delta^{13} \mathrm{C}$ (Table 1). Seven fish from 3 species that were collected opportunistically during 2001 were included in the analysis: 4 jack mackerel Trachurus declivis, 1 rattail Caelorhincus sp. and 2 southern hake Mer-

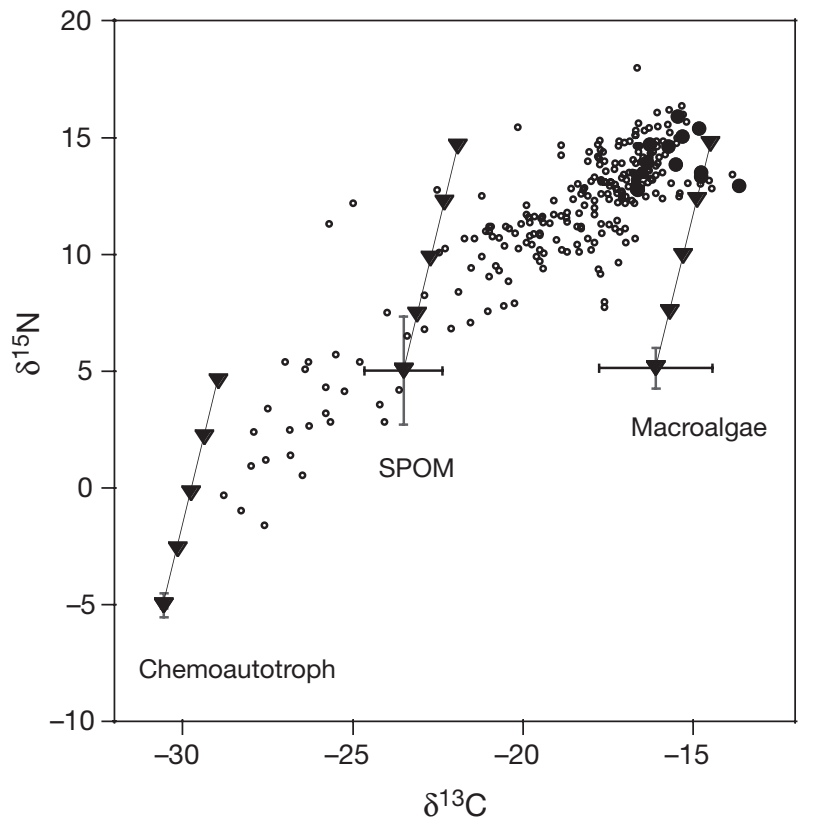

Fig. 2. $\delta^{13} \mathrm{C}$ and $\delta^{15} \mathrm{~N}$ values for the 3 primary carbon sources: chemoautotroph, suspended particulate organic material (SPOM) and macroalgae, with incremental trophic enrichment of $\delta^{15} \mathrm{~N}(+2.4)$ and $\delta^{13} \mathrm{C}(+0.4)(\boldsymbol{\nabla})$; individual fish $\left({ }^{\circ}\right)$; and estimates for individual dolphin diet $(\bullet)$. Error bars indicate $1 \mathrm{SE}$

Table 1. $\delta^{13} \mathrm{C}$ and $\delta^{15} \mathrm{~N}$ of fishes collected in Doubtful Sound, New Zealand. Habitats are pelagic (P), benthopelagic (BP), demersal (D), reef associated (RA), deep basin (DB) and estuarine (ES)

\begin{tabular}{|c|c|c|c|c|c|c|c|c|c|c|c|}
\hline \multirow{2}{*}{ Common name } & \multirow{2}{*}{ Species } & \multirow{2}{*}{ Habitat } & \multirow{2}{*}{$\mathrm{n}$} & \multicolumn{4}{|c|}{$-\delta^{13} \mathrm{C}(\% \circ)$} & \multirow{2}{*}{$\overline{\text { Mean }}$} & \multicolumn{2}{|c|}{$-\delta^{15} \mathrm{~N}(\%)$} & \multirow[b]{2}{*}{ Mas } \\
\hline & & & & Mean & $\mathrm{SE}$ & Min & Max & & SE & Min & \\
\hline Arrow squid & Nototodarus sloanii & $\mathrm{P}$ & 2 & -16.8 & 0.13 & -17.0 & -16.7 & 10.6 & 0.08 & 10.5 & 10.7 \\
\hline Barracouta & Thyrsites atun & $\mathrm{BP}$ & 7 & -17.2 & 0.30 & -18.1 & -16.6 & 14.0 & 0.21 & 13.1 & 15.1 \\
\hline Blue cod & Parapercis colias & $\mathrm{D}$ & 48 & -19.1 & 0.32 & -22.5 & -15.7 & 11.8 & 0.24 & 10.1 & 15.6 \\
\hline Blue mackerel & Scomber australasicus & $\mathrm{P}$ & 1 & -17.4 & & & & 12.9 & & & \\
\hline Butterfly perch & Caesioperca lepidoptera & RA & 5 & -16.2 & 0.10 & -16.5 & -15.9 & 14.6 & 0.16 & 14.2 & 14.9 \\
\hline Conger eel & Conger verreauxi & RA & 1 & -16.1 & & & & 12.6 & & & \\
\hline Girdled wrasse & Notolabrus cinctus & RA & 3 & -16.2 & 0.14 & -16.5 & -15.7 & 14.3 & 0.62 & 13.1 & 16.2 \\
\hline Hapuku & Polyprion oxygeneios & $\mathrm{D}$ & 8 & -17.0 & 0.11 & -17.7 & -16.6 & 14.1 & 0.73 & 12.7 & 20.3 \\
\hline Hagfish & Eptatretus cirrhatus & DB & 39 & -23.6 & 0.63 & -28.0 & -16.7 & 6.3 & 0.81 & -1.6 & 15.5 \\
\hline Jack mackerel & Trachurus declivis & $\mathrm{P}$ & 5 & -17.4 & 0.41 & -18.1 & -15.4 & 10.4 & 0.67 & 9.2 & 12.6 \\
\hline Sea perch & Helicolenus percoides & $\mathrm{D}$ & 59 & -17.5 & 0.20 & -22.5 & -15.2 & 12.8 & 0.18 & 7.6 & 14.7 \\
\hline Pearlsides & Maurolicus muelleri & $\mathrm{P}$ & 5 & -18.4 & 0.68 & -19.1 & -17.6 & 12.8 & 0.46 & 12.3 & 13.6 \\
\hline Rattail species & Caelorinchus spp. & DB & 3 & -19.3 & 1.07 & -20.6 & -17.2 & 8.5 & 0.59 & 7.8 & 9.7 \\
\hline Red cod & Pseudophycis bachus & $\mathrm{D}$ & 4 & -15.8 & 0.58 & -17.3 & -14.5 & 13.3 & 0.59 & 12.4 & 15.0 \\
\hline Red gurnard & Chelidonichthys kumu & $\mathrm{D}$ & 5 & -15.8 & 0.73 & -18.4 & -13.8 & 13.7 & 0.97 & 10.1 & 15.6 \\
\hline Redbait & Emmelichthys nitidus & $\mathrm{D}$ & 6 & -16.9 & 0.11 & -17.2 & -16.5 & 12.8 & 0.19 & 12.2 & 13.5 \\
\hline Redbait (juveniles) & Emmelichthys nitidus & $\mathrm{P}$ & 5 & -19.3 & 0.11 & -19.5 & -18.9 & 11.5 & 0.06 & 11.3 & 11.7 \\
\hline Sand flounder & Rhombosolea plebeia & ES & 4 & -18.8 & 1.35 & -22.9 & -17.3 & 8.4 & 0.93 & 6.8 & 11.1 \\
\hline Scarlet wrasse & Pseudolabrus miles & RA & 3 & -15.8 & 0.24 & -16.1 & -15.3 & 16.0 & 0.26 & 15.5 & 16.4 \\
\hline School shark & Galeorhinus galeus & $\mathrm{BP}$ & 3 & -16.1 & 0.35 & -16.7 & -15.5 & 14.1 & 0.37 & 13.5 & 14.8 \\
\hline Southern hake & Merluccius australis & $\mathrm{BP}$ & 3 & -18.0 & 0.39 & -18.7 & -17.5 & 11.3 & 0.19 & 10.9 & 11.6 \\
\hline Spiny dogfish & Squalus acanthias & $\mathrm{BP}$ & 3 & -18.3 & 0.90 & -19.8 & -16.7 & 12.4 & 0.43 & 11.6 & 13.0 \\
\hline Spotty & Notolabrus celidotus & ES & 14 & -18.7 & 0.42 & -21.7 & -15.7 & 11.5 & 0.27 & 10.2 & 13.1 \\
\hline Tarakihi & Nemadactylus macropterus & $S \quad \mathrm{D}$ & 11 & -17.5 & 0.79 & -21.5 & -14.5 & 12.5 & 0.73 & 9.43 & 16.0 \\
\hline
\end{tabular}


luccius australis. Two specimens of arrow squid Nototodarus sloanii were also included. Twenty-six sea perch Helicolenus percoides and 34 blue cod Parapercis colias that were collected in 2004 were also included to increase sample size for these 2 species. The juveniles of redbait Emmelichthys nitidis were treated as separate from adults as their basic ecology differs significantly: the adults are largely demersal, whereas the juveniles are strictly pelagic.

The stable carbon and nitrogen values of muscle tissue of fishes and squid, without lipid extraction, covered a considerable range (Table 1, Figs 2 \& 3). Values of $\delta^{15} \mathrm{~N}$ ranged from -1.6\% in the hagfish Eptatretus cirrhatus to $20.3 \%$ in the hapuku Polyprion oxygeneios. The lowest $\delta^{13} \mathrm{C}$ value was similarly found in hagfish $(-28.0 \%$ o) and the highest value of $-13.8 \%$ occurred in the red gurnard Chelidonichthys kumu (Table 1). $\delta^{13} \mathrm{C}$ and $\delta^{15} \mathrm{~N}$ also covered a considerable range within some species. Hagfish E. cirrhatus, blue cod P. colias, sea perch $H$. percoides and tarakihi Nemadactylus macropterus showed the largest isotopic variation within species, which may reflect a varied diet including macroalgal and phytoplankton consumers as well as chemoautotrophs (Table 1, Fig. 2). The continuous distribution of isotopic values of individual fishes reflected the distribution of isotopic signatures of primary producers in Doubtful Sound (Fig. 2). This pattern was also apparent in the mean values for each species (Fig. 3) and in the distribution of isotopic values of fishes from different habitats (Fig. 4).

\section{Groupings of fishes}

The cluster analysis of the mean $\delta^{13} \mathrm{C}$ and $\delta^{15} \mathrm{~N}$ for the 24 species identified 3 groups according to variation in isotopic signature (Fig. 3). Group 1 consisted of only 1 species, hagfish Eptatretus cirrhatus, with an average $\delta^{15} \mathrm{~N}$ value of $6.3 \%$ and an average $\delta^{13} \mathrm{C}$ value of $-23.6 \%$. Hagfish are associated with the deep basins, but are also frequently encountered on muddy sediments in estuarine bays and on the rock reefs. Group 2 contained species spanning the widest range of mean carbon-isotope values, ranging from $-19.3 \%$ for juvenile redbait and rattails to $-16.9 \%$ for arrow squid and adult redbait (Table 1, Fig. 3). $\delta^{15} \mathrm{~N}$ values ranged between $8.4 \%$ for sand flounder to $12.9 \%$ for blue mackerel Scomber australasicus (Table 1). All the species categorised as having a pelagic habitat fell within this group, as did the spotty Notolabrus celidotus, which is frequently encountered in the estuarine habitats (Fig. 3). Jack mackerel and arrow squid stood out within this group, displaying both high $\delta^{13} \mathrm{C}$ values and low $\delta^{15} \mathrm{~N}$ values (Table 1). Group 3 was composed primarily of demersal and reef-associated species

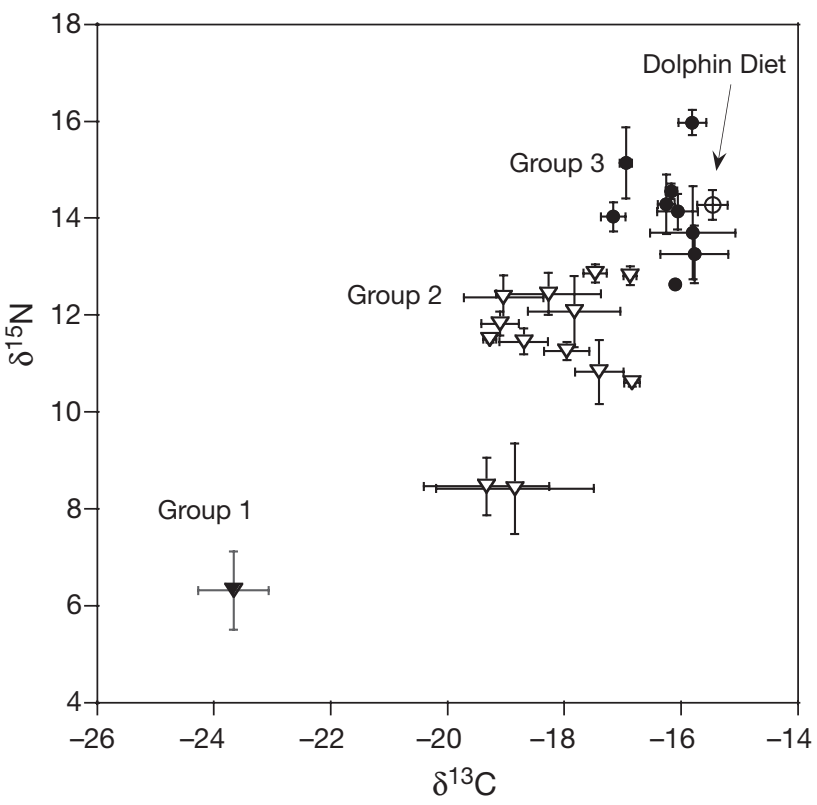

Fig. 3. Mean $\delta^{13} \mathrm{C}$ and $\delta^{15} \mathrm{~N}$ values for each fish species and estimates of dolphin diet. $\mathbf{\nabla}$ : Fish in cluster Group $1,(\nabla$ : Group 2 and $\bullet$ : Group 3. O: estimate of dolphin diet. Error bars indicate $1 \mathrm{SE}$

(Fig. 3). Members of this group displayed the most enriched values for $\delta^{13} \mathrm{C}$ and $\delta^{15} \mathrm{~N}$, and ranged from 12.6 to $16.0 \%$ in $\delta^{15} \mathrm{~N}$ and from -17.2 to $-15.8 \%$ o for $\delta^{13} \mathrm{C}$ (Table 1). Although some overlap exists between the 3 groups, especially in terms of $\delta^{15} \mathrm{~N}$ values, the combination of carbon and nitrogen isotopes clearly distinguished the groups. Discriminant analysis indicated that the groups were indeed significantly different from one another (all Fisher's $F_{\text {Mahalanobis distances }}>$ $7.8, \mathrm{p}<0.05)$. Results from ANOVA show that the 3 groups are significantly different for $\delta^{15} \mathrm{~N}\left(F_{23,235}=\right.$ 13.41, $\mathrm{p}<0.0001)$ and $\delta^{13} \mathrm{C}\left(F_{23,235}=12.17, \mathrm{p}<0.0001\right)$ with post-hoc Tukey's tests on both $\delta^{15} \mathrm{~N}$ and $\delta^{13} \mathrm{C}$ showing significant differences among the 3 groups but not between Group 3 and estimates of dolphin diet (Group $1<$ Group $2<$ Group 3 = Dolphin Diet).

\section{Habitat association among fishes}

Results from analysis of habitat associations reveal distinct groupings of $\delta^{13} \mathrm{C}$ and $\delta^{15} \mathrm{~N}$ for fishes from common habitats (Fig. 4). These groups have predictable signatures relative to the carbon sources: 'deep basin' associated with the extremely depleted isotopic signatures of recycled terrestrial production, 'pelagic' associated with SPOM and 'reef associated' species enriched in both ${ }^{15} \mathrm{~N}$ and ${ }^{13} \mathrm{C}$, likely by macroalgal carbon sources (Fig. 4). Results of the ANOVA on $\delta^{15} \mathrm{~N}$ show significant differences among some habitat 


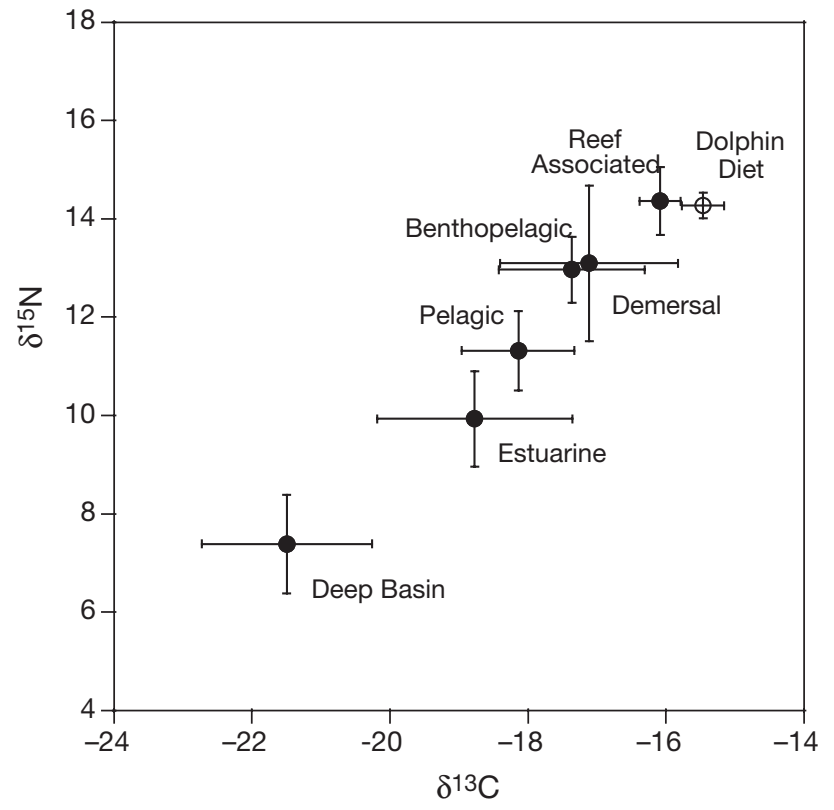

Fig. 4. Mean $\delta^{13} \mathrm{C}$ and $\delta^{15} \mathrm{~N}$ values for fishes in each habitat group (๑), and estimate of dolphin diet (O). Error bars indicate $1 \mathrm{SE}$

groups $\left(F_{23,235}=12.17, \mathrm{p}<0.0001\right)$. A post-hoc Tukey's test demonstrates that $\delta^{15} \mathrm{~N}$ of the dolphin diet is not significantly different from those of demersal, benthopelagic and reef-associated fishes, but significantly different from pelagic, estuarine and deep-basin fishes. Results from the ANOVA on $\delta^{13} \mathrm{C}$ show significant differences among habitat groupings $\left(F_{23,235}=\right.$ 13.41, p $<0.0001)$. A post-hoc Tukey's test reveals that $\delta^{13} \mathrm{C}$ of the dolphin diet is not significantly different from reef-associated and benthopelagic groups, but significantly different from each of the other groups.

\section{Bottlenose dolphin skin samples}

Fifteen samples of exfoliated skin (es1 to 15) were obtained from bottlenose dolphins in Doubtful Sound, with minimal consequences to the animals. These 15 samples ranged in dry weight from 0.03 to $1.16 \mathrm{mg}$, averaging $0.31 \mathrm{mg}$ (Table 2). Sample es1 was omitted because target precision of 0.2 was not reached in the mass-spectrometer measurements. The $\delta^{15} \mathrm{~N}$ values of the remaining 14 exfoliated skin samples ranged from 13.4 to $17.1 \%$ and $\delta^{13} \mathrm{C}$ between -14.0 and $-18.3 \%$ (Table 2). Three samples (es13, es14 and es15) were not analysed for $\delta^{15} \mathrm{~N}$, and these were not included in the statistical analyses. The average values for the remaining 11 samples was $15.1 \pm 0.36 \%$ o $\left(\delta^{15} \mathrm{~N}, \mathrm{n}=11\right)$ and $-16.5 \pm 0.38 \%$ o $\left(\delta^{13} \mathrm{C}\right.$, mean $\left.\pm \mathrm{SE}, \mathrm{n}=11\right)$. Skin samples collected in June averaged $-15.7 \%$ for $\delta^{13} \mathrm{C}$ and
$14.8 \%$ for $\delta^{15} \mathrm{~N}$. Samples from October had similar $\delta^{15} \mathrm{~N}$ values $\left(15.1 \%\right.$ ) but were depleted in $\delta^{13} \mathrm{C}(-17.4 \%)$ relative to the June samples. The 2 samples from April averaged $15.9 \%$ for $\delta^{15} \mathrm{~N}$ and $-16.7 \%$ or $\delta^{13} \mathrm{C}(-16.9 \%$ if all 5 were considered) and were thus intermediate between samples from the 2 other periods. However, these differences were not statistically significant (Wilk's $\lambda=0.52, F_{4,14}=1.37, \mathrm{p}=0.30$ ), potentially due to the low sample size and resulting large variation within samples from each period.

\section{Diet of bottlenose dolphin}

With corrections for trophic level, it was estimated that the assimilated diet of individual bottlenose dolphins had stable-isotopic values ranging from 12.75 to $15.89 \%$ for $\delta^{15} \mathrm{~N}$ and -16.6 to $-13.7 \%$ for $\delta^{13} \mathrm{C}$ (Fig. 2). This resulted in a mean value $( \pm \mathrm{SE})$ of $14.18 \pm 0.31 \%$ for $\delta^{15} \mathrm{~N}$ and $-15.38 \pm 0.26 \%$ ofor $\delta^{13} \mathrm{C}$ (Fig. 3 ).

These values were compared to isotopic values of the prey base in Doubtful Sound. Estimated dietary values of individual dolphins overlapped isotopic values of individual fishes with the most-enriched values of both $\delta^{15} \mathrm{~N}$ and $\delta^{13} \mathrm{C}$ (Fig. 2). The enriched $\delta^{15} \mathrm{~N}$ and $\delta^{13} \mathrm{C}$ of estimates of dolphin diet indicate that the mixture of prey species used by these dolphins had $\delta^{15} \mathrm{~N}$ and $\delta^{13} \mathrm{C}$ similar to fish species found in Group 3 (Fig. 3): those with a strong association with rocky reefs and other benthic habitats in Doubtful Sound (Fig. 5). This pattern is also reflected in Fig. 4, which indicates that the estimates for $\delta^{13} \mathrm{C}$ and $\delta^{15} \mathrm{~N}$ of assimilated diet were more similar to those of reef-associated and other demersal fishes than to pelagic fishes

Table 2. Tursiops sp. $\delta^{13} \mathrm{C}$ and $\delta^{15} \mathrm{~N}$ of exfoliated skin samples collected from bottlenose dolphins in Doubtful Sound

\begin{tabular}{|llccc|}
\hline $\begin{array}{l}\text { Month } \\
\text { sampled }\end{array}$ & Label & $\begin{array}{c}\text { Weight } \\
(\mathrm{mg})\end{array}$ & $\begin{array}{c}\delta^{15} \mathrm{~N} \\
(\%)\end{array}$ & $\begin{array}{c}\delta^{13} \mathrm{C} \\
(\%)\end{array}$ \\
\hline Jun & es 1 & 0.74 & 16.3 & -11.7 \\
& es 2 & 0.08 & 14.1 & -15.6 \\
& es 3 & 0.26 & 13.6 & -14.0 \\
& es 4 & 0.03 & 17.1 & -16.6 \\
& es5 & 0.05 & 14.7 & -16.7 \\
\multirow{6}{*}{ Oct } & es6 & 0.24 & 14.3 & -15.6 \\
& es7 & 0.18 & 13.4 & -18.3 \\
& es 8 & 0.37 & 14.8 & -17.9 \\
& es 9 & 1.16 & 16.5 & -15.7 \\
& es 10 & 0.43 & 15.7 & -17.8 \\
& es 11 & 0.56 & 16.1 & -16.4 \\
& es 12 & 0.39 & 15.6 & -17.0 \\
& es 13 & 0.03 & - & -18.0 \\
& es 14 & 0.14 & - & -16.9 \\
& es 15 & 0.04 & - & -16.2 \\
\hline
\end{tabular}



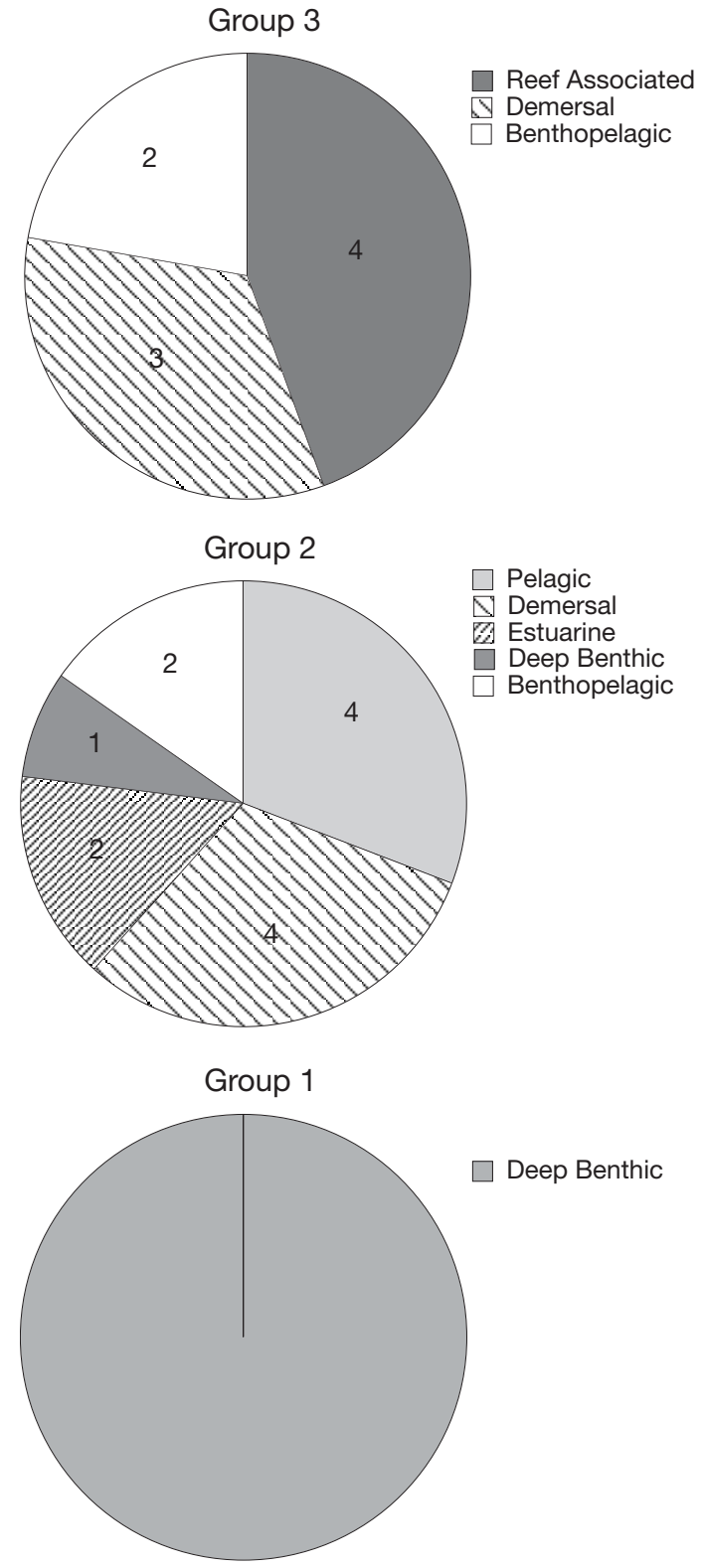

Fig. 5. Numbers of fish species from each habitat grouping for each of the 3 cluster groups

or fishes from the deep basins. The position of diet values, at the end of the distribution of fish isotopic values, indicates that a negligible amount of mixing of the different sources was likely.

\section{Mixing model}

Results from analysis using the 'isoerror' mixing model indicate that macroalgae likely contribute a larger fraction of carbon to the fishes that make up dolphin diet than SPOM or chemoautrophic production

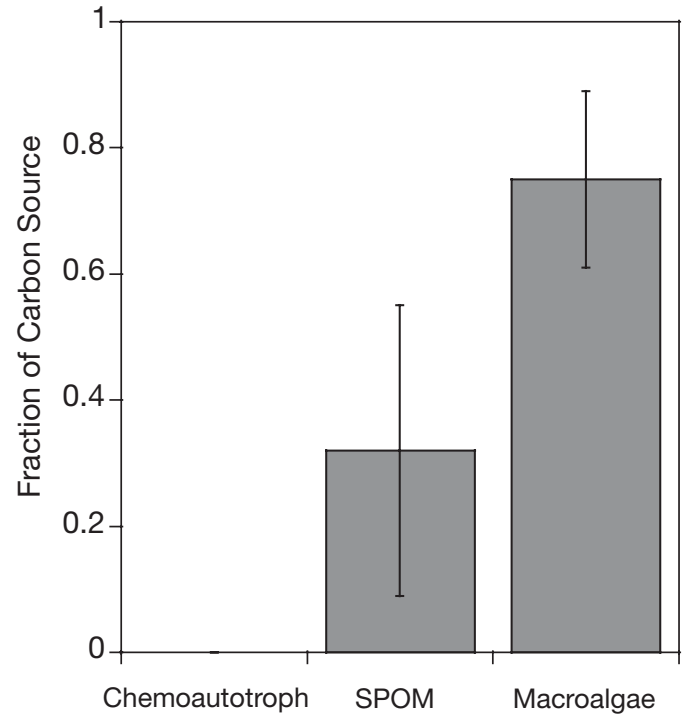

Fig. 6. Estimates of mean fraction of each primary carbon source-chemoautotroph, SPOM and macroalgae-contributing to dolphin diet. Error bars indicate $1 \mathrm{SE}$

(Fig. 6). Because these results are sensitive to assumptions about incremental trophic enrichment, we ran several cases $\left(\delta^{13} \mathrm{C}+0.4\right.$ to $+1.3, \delta^{15} \mathrm{~N}+2.4$ to +2.9$)$ in accordance with published values from McCutchan et al. (2003) in the model with similar results to the basic case $\left(\delta^{13} \mathrm{C}+0.4, \delta^{15} \mathrm{~N}+2.4\right)$.

\section{DISCUSSION}

The results of this study demonstrate that habitatspecific groups of fishes from Doubtful Sound can be discriminated by $\delta^{15} \mathrm{~N}$ and $\delta^{13} \mathrm{C}$ and closely reflect the range of isotopic variability of primary carbon sources in the system. This makes it possible to use stableisotope analysis in dietary studies of higher-level predators such as bottlenose dolphins in the system. Analyses of $\delta^{15} \mathrm{~N}$ and $\delta^{13} \mathrm{C}$ of dolphin skin samples, and likely combinations of diet that contribute to these signatures, suggest that the bottlenose dolphin population derives most of its energy from reef-associated and demersal fishes.

The assimilation of carbon from several isotopically distinct sources of primary production within Doubtful Sound likely contributed to the large variation in $\delta^{15} \mathrm{~N}$ and $\delta^{13} \mathrm{C}$ within some fishes, particularly the hagfish Eptatretus cirrhatus. This species is a scavenger and opportunistic predator, and its diet consists of benthic macrofauna as well as animals that fall into the deep basins from the surrounding habitats. The very depleted isotopic signatures observed in some individuals (e.g. $\delta^{15} \mathrm{~N}-3 \%$, $\delta^{13} \mathrm{C}-28 \%$ ) may indicate incorporation 
of recycled production in the form of chemoautosynthetic organisms such as Solemya parkinsoni. For example, studies of hagfish nutrition have attributed similar depleted isotopic signatures to recycled production from chemoautotrophic assemblages in connection to hydrocarbon seeps (e.g. MacAvoy et al. 2002). Some individuals of blue cod Parapercis colias and sea perch Helicolenus percoides also displayed depleted isotopic signatures and a high dietary incidence of the chemoautotrophic clam $S$. parkinsoni, which has a very depleted isotopic signature $\left(\delta^{15} \mathrm{~N}\right.$ $-5 \%$, $\delta^{13} \mathrm{C}-30 \%$; S. R. Wing et al. unpubl. data).

The link from primary producers to fishes occupying different habitats was further emphasised when $\delta^{15} \mathrm{~N}$ and $\delta^{13} \mathrm{C}$ of fishes from each habitat were averaged. Reef-associated fishes such as scarlet wrasse Pseudolabrus miles, girdled wrasse Notolabrus cinctus and butterfly perch Caesioperca lepidoptera, and demersal species such as red cod Pseudophycis bachus and red bait Emmelichthys nitidus, are among the most numerous fishes encountered along the reefs inside the fjord (Francis \& Ling 1985). These species as well as the red gurnard Chelidonichthys kumu, hapuku Polyprion oxygeneios and conger eel Conger verreauxi had enriched $\delta^{15} \mathrm{~N}$ and $\delta^{13} \mathrm{C}$, reflecting the enriched isotopic signature of macroalgae, an important energy source in the shallow reef and demersal habitats. The investigated pelagic species, which likely derive more of their energy from the phytoplankton-based food web, had more depleted values of $\delta^{15} \mathrm{~N}$ and $\delta^{13} \mathrm{C}$, reflecting the influence of SPOM. While each of these species certainly makes use of a mixture of carbon sources, the range of values for $\delta^{15} \mathrm{~N}$ and $\delta^{13} \mathrm{C}$ allowed for isotopic discrimination of species by habitat.

The species composition of the cluster groups of fishes (Fig. 3) was described in terms of habitat associations of individual species (Fig. 5). It was not scaled according to biomass of the species in the fjord, their general availability or catchability to predators in the system. This indicates that, although bottlenose dolphin diet was estimated to overlap with fishes in Group 3, the diet did not necessarily comprise fishes from the 3 habitats in the proportions in which they were found in this group. However, the analysis does enable exclusion of groups of fishes. It is unlikely that pelagic fishes or fishes from the deep basins have been assimilated in large amounts. This conclusion relies on the fact that the position of $\delta^{15} \mathrm{~N}$ and $\delta^{13} \mathrm{C}$ for dolphin diet, at the enriched end of the observed distribution of $\delta^{13} \mathrm{C}$ and $\delta^{15} \mathrm{~N}$ for fishes, indicates a negligible amount of mixing of the different sources (Phillips \& Gregg 2001). In addition, the results of analysis using the multiple-source mixing model (Phillips \& Gregg 2001) indicate that the population of bottlenose dolphins relies in a large part on the macroalga-based carbon associated with rocky-reef and benthic habitats. This pattern likely represents use of autochthonous carbon, although the possibility exists that demersal and reefassociated species could migrate from the outer coast into the fjord. It is also possible that we missed some important fish species in the system, although the most abundant were identified and sampled.

The present study did not detect any changes in the isotopic signature of predators or prey during the year, or among years of sampling. However, it must be noted that these comparisons were made for a limited number of species. Considerable temporal differences in isotopic signature have been observed in other studies (e.g. Kline 1997), as have differences on relatively small spatial scales (Lesage et al. 2001). Whether the pattern in isotopic signatures observed here for all species is stable over seasons or years would require further research. This uncertainty merely highlights the need for concurrent sampling of predators and prey when using stable-isotope analysis in diet studies such as this one.

The results of the present study rely on the assumption that diet-tissue fractionation in the bottlenose dolphin is similar to that observed for other mammals (Hobson et al. 1996, Roth \& Hobson 2000). The close overlap between isotopic signature of individual fishes and estimated diet for individual dolphins indicates that the conversion factor used was likely appropriate. Furthermore, the diet-tissue fractionation values would have to have been 2 to 3 times greater than the ones used in this study to significantly alter the conclusions.

The exfoliated skin samples collected from Doubtful Sound weighed considerably less than the recommended sample size (e.g. Boutton 1991). However, the low variation and high precision achieved indicates that they provided reliable estimates for the tissue. This was supported by consistent readings of similarly sized control samples of known isotopic composition run every third sample. This study demonstrates that, at least for bottlenose dolphins, stable-isotope analysis of exfoliated skin tissue can give reliable results, providing there is the opportunity to sample these and other small cetaceans with minimal disturbance or interference to the animal.

The conclusions of the present study are consistent with the observations by Schneider (1999), that the dolphins in Doubtful Sound spend more than $70 \%$ of their time in close proximity to the shoreline, possibly feeding individually along the rocky reefs. Even when diving in mid-water preliminary data suggest that many of the synchronous dives observed occur above underwater pinnacles or sills between basins (D. Lusseau pers. comm.). Demersal and reef-associated fishes typically aggregate in such locations due to 
increased shelter and food availability. This observation is also consistent with studies of other coastal populations of bottlenose dolphins, which were found to have a large dietary component of solitary demersal species, in contrast to oceanic populations, which had a large component of schooling pelagic fishes in their diet (e.g. Barros \& Wells 1998). The bottlenose dolphin population in Doubtful Sound has access to both general habitat zones within its home range. In this case pelagic fishes represent an ephemeral food source, most abundant during the summer months. In contrast, the fishes inhabiting the reefs and other demersal habitats likely represent a more reliable but limited resource.

Epidermal tissue of bottlenose dolphins has a turnover rate of approximately $73 \mathrm{~d}$ (Hicks et al. 1985). $\delta^{13} \mathrm{C}$ and $\delta^{15} \mathrm{~N}$ of exfoliated skin analysed in this study thus represent diet assimilated over the late summer, autumn and winter, provided new energy stores are being used for tissue growth. Isotopic signatures of exfoliated skin were not significantly different among these 3 periods, suggesting similar diet among sample periods. The results indicate that, although pelagic fishes are abundant during the summer months, the dolphins did not rely extensively on this food source during the late summer period or any other times of the year sampled.

The work presented here provides new information about the food-web dynamics of deep fjords. Due to the steep-sided topography, productive littoral regions of deep fjords are much smaller than the marine surface area (Burrell 1988). Deep fjords thus appear, at first glance, to be primarily pelagic systems with phytoplankton the dominant form of primary production (Burrell 1988). However, the results from this study indicate that the shallow reef zone along the rock walls with its associated macroalgal production could be a much more important source of energy to the system than generally assumed.

Marine mammals can have a major effect on the structure and function of marine communities, due to their abundance, size and trophic position (Katona \& Whitehead 1988, Bowen 1997). For example, Young \& Phillips (2002) estimated that between 3 and $7 \%$ of total primary production in a salt-marsh estuarine creek system was used to support bottlenose dolphin predation during the summer months. This fraction increased to as much as $41 \%$ during low primary productivity in the winter months (Young \& Phillips 2002). This estimated magnitude of carbon use demonstrates that a substantial proportion of the energy generated within a coastal system may be required to support populations of resident top predators. If the bottlenose dolphins in Doubtful Sound are primarily supported by autochthonous production, as this study suggests, then the fraction of primary production required for their maintenance may be high. The habitats in Doubtful Sound that were identified as important suppliers of energy to the dolphins are highly fragmented inside the fjord, as well as spatially isolated from similar habitats in neighbouring fjords. It is unlikely that decreases in local abundance of prey will be quickly compensated by an influx of fishes from neighbouring areas. Changes to the availability of prey fishes either through direct competition with fisheries or through environmental changes (natural or anthropogenic) in Doubtful Sound may have direct effects on the viability of the bottlenose dolphin population as well as other predators relying on production generated inside the fjord.

Acknowledgements. We thank R. Frew, R. McLeod, D. Lusseau, K. Schneider, B. Dickson, S. Dawson, P. Duignan and $\mathrm{O}$. Boisseau for valuable contributions to this research. Support was provided by the University of Otago Research Committee and from the Marsden Fund (UOO038).

\section{LITERATURE CITED}

Barros NB, Wells RS (1998) Prey and feeding patterns of resident bottlenose dolphins (Tursiops truncates) in Sarasota Bay, Florida. J Mar Mammol 79:1045-1059

Boutton TW (1991) Stable carbon isotope ratios of natural materials: I. Sample preparation and mass spectrometric analysis. In: Coleman DC, Fry B (eds) Carbon isotope techniques. Academic Press, San Diego, CA, p 155-173

Bowen WD (1997) Role of marine mammals in aquatic ecosystems. Mar Ecol Prog Ser 158:267-274

Burrell DC (1988) Carbon flow in fjords. Oceanogr Mar Biol Annu Rev 26:143-226

Cockroft VG, Ross GJB (1990) Food and feeding of the Indian Ocean bottlenose dolphin off southern Natal, South Africa. In: Leatherwood S, Reeves RR (eds) the bottlenose dolphin. Academic Press, San Diego, CA, p 309-323

Corkeron PJ, Bryden MM, Hedstrom KE (1990) Feeding by bottlenose dolphins in association with trawling operations in Moreton Bay, Australia. In: Leatherwood S, Reeves RR (eds) The bottlenose dolphin. Academic Press, San Diego, CA, p 329-337

Das K, Lepoint G, Leroy Y, Bouquegneau JM (2003) Marine mammals from the southern North Sea: feeding ecology data from $\delta^{13} \mathrm{C}$ and $\delta^{15} \mathrm{~N}$ measurements. Mar Ecol Prog Ser 263:287-298

DeNiro MJ, Epstein S (1978) Influence of diet on the distribution of carbon isotopes in animals. Geochim Cosmochim Acta 42:495-506

DeNiro MJ, Epstein S (1981) Influence of diet on the distribution of nitrogen isotopes in animals. Geochim Cosmochim Acta 45:341-351

France RL (1995) Carbon-13 enrichment in benthic compared to planktonic algae: food web implications. Mar Ecol Prog Ser 124:307-312

Francis MP (1988) Coastal fishes of New Zealand: an identification guide, 3rd edn. Reed Books, Auckland

Francis MP, Ling N (1985) Abundance of reef fish in Doubtful and Thompson Sounds, Fiordland. Report 32, New Zealand Fisheries Research Division, Wellington

Fry B, Sherr EB (1984) $\delta^{13} \mathrm{C}$ measurements as indicators of 
carbon flow in marine and freshwater ecosystems. Contrib Mar Sci 27:13-47

Gibbs M, Bowman M, Dietrich D (2000) Maintenance of near surface stratification in Doubtful Sound a New Zealand fjord. Estuar Coast Shelf Sci 51:683-704

Goebel NL, Wing SR, Boyd PW (2005) A mechanism for onset of diatom blooms in a fjord with persistent salinity stratification. Estuar Coast Shelf Sci 64:546-560

Grange K, Singleton R, Richardson J, Hill P, del Main W (1981) Shallow rock-wall biological associations of some southern fiords of New Zealand. NZ J Zool 8:209-227

Haase PA, Schneider K (2001) Birth demographics of bottlenose dolphins, Tursiops truncates, in Doubtful Sound, Fiordland, New Zealand-preliminary findings. NZ J Mar Freshw Res 35:675-680

Harlin AD, Würsig B, Baker CS, Markowitz TM (1999) Skin swabbing for genetic analysis: application to dusky dolphins (Lagenorhynchus obscurus). Mar Mamm Sci 15: 409-425

Hicks BD, St Aubin DJ, Geraci JR, Brown WR (1985) Epidermal growth in the bottlenose dolphin, Tursiops truncatus. J Invest Dermatol 85:60-63

Hobson KA, Schell DM, Renouf D, Noseworthy E (1996) Stable-carbon and nitrogen fractionation between diet and tissues of captive seals: implications for dietary reconstruction involving marine mammals. Can J Fish Aquat Sci 53:528-533

Kastelein RA, Vaughan N, Walton S, Wiepkema PR (2002) Food intake and body measurements of Atlantic bottlenose dolphins (Tursiops truncates) in captivity. Mar Environ Res 53:199-218

Katona S, Whitehead H (1988) Are Cetacea ecologically important? Oceanogr Mar Biol Annu Rev 26:553-568

Kline TC (1997) Temporal and spatial variability of $\delta^{13} \mathrm{C} / \delta^{12} \mathrm{C}$ and $\delta^{15} \mathrm{~N} / \delta^{14} \mathrm{~N}$ in pelagic biota of Prince William Sound, Alaska. Can J Fish Aquat Sci 56:94-117

Lesage V, Hammill MO, Kovacs KM (2001) Marine mammals and the community structure of the estuary and Gulf of St Lawrence, Canada; evidence from stable isotope analysis. Mar Ecol Prog Ser 210:203-221

Lusseau D, Schneider K, Boisseau OJ, Haase P, Slooten E, Dawson SM (2003) The bottlenose dolphin community of Doubtful Sound features a large proportion of longlasting associations - can geographic isolation explain this unique trait? Behav Ecol Sociobiol 54:396-405

MacAvoy SE, Carney RS, Fisher CR, Macko SA (2002) Use

Editorial responsibility: Otto Kinne (Editor-in-Chief), Oldendorf/Luhe, Germany of chemosynthetic biomass by large, mobile, benthic predators in the Gulf of Mexico. Mar Ecol Prog Ser 225: $65-78$

McCutchan JH, Lewis WM, Kendall C, McGrath CC (2003) Variation in trophic shift for stable isotope ratios of carbon, nitrogen and sulfur. Oikos 102:378-390

Perrin C, Wing SR, Roy MS (2004) Population genetic structure amongst populations of the sea star Coscinasterias muricata in the New Zealand fjords. Molec Ecol 13: 2183-2195

Peterson BJ, Fry B (1987) Stable isotopes in ecosystems studies. Annu Rev Ecol Syst 18:293-320

Phillips DL, Gregg JW (2001) Uncertainty in source partitioning using stable isotopes. Oecologia 127:171-179

Pickrill RA (1987) Circulation and sedimentation of suspended particulate matter in New Zealand fiords. Mar Geol 74:21-39

Pinnegar JK, Polunin NVC (1999) Differential fractionation of $\delta^{13} \mathrm{C}$ and $\delta^{15} \mathrm{~N}$ among fish tissues: implications for the study of trophic interactions. Funct Ecol 13:225-231

Rau GH, Ainley DG, Bengtson JL, Torres JJ, Hopkins TL (1992) $\delta^{15} \mathrm{~N} / \delta^{14} \mathrm{~N}$ and $\delta^{13} \mathrm{C} / \delta^{12} \mathrm{C}$ in Weddell Sea birds, seals and fish: implications for diet and trophic structure. Mar Ecol Prog Ser 84:1-8

Roth JD, Hobson KA (2000) Stable carbon and nitrogen isotopic fractionation between diet and tissue of captive red fox: implications for dietary reconstruction. Can J Zool 78: $848-852$

Rutger SM, Wing SR (2006) Effects of freshwater input on shallow water infaunal communities in Doubtful Sound, New Zealand. Mar Ecol Prog Ser 314:35-47

Schneider K (1999) Behaviour and ecology of bottlenose dolphins in Doubtful Sound. PhD thesis, University of Otago

Tieszen LL, Boutton TW, Tesdahl KG, Slade NA (1983) Fractionation and turnover of stable carbon isotopes in animal tissues: implications for $\delta^{13} \mathrm{C}$ analysis of diet. Oecologia 57: 32-37

Urian KW, Duffield DA, Read AJ, Wells RS, Shell ED (1996) Seasonal of reproduction in bottlenose dolphins, Tursiops truncates. J Mammol 77:394-403

Wada E, Mizutani H, Minagawa M (1991) The use of stable isotopes for food web analysis. Crit Rev Food Sci Nutrit 30: 361-371

Young RF, Phillips HD (2002) Primary production required to support bottlenose dolphins in a salt marsh estuarine creek system. Mar Mamm Sci 18:358-373

Submitted: November 3, 2005; Accepted: March 13, 2006

Proofs received from author(s): August 28, 2006 